\title{
PENGEMBANGAN PERANGKAT PEMBELAJARAN BERBASIS SAINTIFIK MENGGUNAKAN MODUL TATA NAMA SENYAWA
}

\section{DEVELOPMENT OF SCIENTIFIC BASED LEARNING DEVICES USING COMPOUND MONENCLATURE MODULE}

\author{
Efri Pamisa*, Lisa Ariyanti Pohan, Wildawani Siregar \\ Universitas Islam Sumatera Utara, Departement of Chemistry Education, Medan 20217, \\ North Sumatera, Indonesia \\ ${ }^{*}$ Corresponding author: efripamis88@gmail.com
}

\begin{abstract}
ABSTRAK
Penelitian ini dilakukan berdasarkan analisis kebutuhan yang menunjukan guru masih kesulitan dalam membuat perangkat pembelajaran. Tujuan penelitian ini adalah menghasilkan suatu produk perangkat pembelajaran berupa RPP dan MODUL berbasis saintifik untuk materi tata nama senyawa siswa kelas X Sekolah Menengah Atas.Penelitian ini menggunakan metode Research and Development (R\&D). Langkah-langkah pengembangan penelitian ini (1) analisis kebutuhan, (2) penelitian dan pengumpulan data, (3) pengembangan produk awal, (4) evaluasi, (5) revisi, (6) penyempurnaan produk akhir. Instrumen yang digunakan dalam penelitian ini adalah angket untuk memvalidasi kualitas perangkat pembelajaran berbasis saintifik oleh pakar pembelajaran dan guru kelas X Sekolah Menengah Atas.Perangkat pembelajaran berbasis saintifik untuk siswa kelas X dikembangkan dengan sangat baikdan layak digunakan berdasarkan validasi pakar pembelajaran dengan skor $82 \%$ dan pakar media dengan skor $77 \%$. Penilaian perangkat pembelajaran berbasis saintifik sangat layak digunakan berdasarkan validasi guru kelas X dengan skor $84 \%$.
\end{abstract}

Kata Kunci : Perangkat pembelajaran; RPP dan MODUL berbasis saintifik; tata nama senyawa.

\begin{abstract}
This research was conducted based on needs analysis which shows that teachers stil have difficulty in making learning devices. The purpose of this study was to produce a learning device product in the form of Lesson Plans and Scientific-based MODULE for compound nomenclature material for high school student in class X.This study uses the Research and Developmen $(R \& D)$ method. The steps to develop this research are (1) needs analtsis, (2) research and datacollection, (3) intial product development, (4) evaluatio, (5) revision, (6) final product improvement. The instrument used in this study was a quetionnaire to validate the quality of scientific-based learning devices by learning experts and teachers of class X Senior High School.Scientific-based learning devices for the stidents in class $X$ are very well developed and feasible to use based on the validation of learning experts with a score of $82 \%$ and media experts with a score of 77\%. Assessment of scientific-based learning devices is very feasible based on the validation from the teachers in class $X$ with a score of $84 \%$.
\end{abstract}

Keywords: Learning Devices; Lesson Plans and Scientific-based MODULE; Compound Nomenclature. 


\section{PENDAHULUAN}

Guru yang berkualitas akan selalu menyusun suatu perencanaan untuk proses pembelajarannya, sehingga tidak ada alasan guru ketika mengajar di kelas tanpa perencanaan pembelajaran(Suparmi dkk, 2012). Salah satu aspek dalam perencanaan pembelajaran yaitu guru menyusun suatu perangkat pembelajaran yang akan digunakan selama proses pembelajarannya(Mulyasa, 2011: 21).

Rencana pelaksanaan pembelajaran (RPP) adalah rencana pembelajaran yang dikembangkan secara rinci mengacu pada silabus, buku teks pelajaran, dan buku panduan guru. RPP mencakup: (1) identitas sekolah/madrasah, mata pelajaran, dan kelas/semester; (2) alokasi waktu; (3) KI, KD, indikator pencapaian kompetensi; (4) materi pembelajaran; (5) kegiatan pembelajaran; (6) penilaian; dan (7) media/alat, bahan, serta sumber belajar. RPP yang baik harus sesuai dengan Permendikbud nomor 103 tahun 2014 tentang pembelajaran pada pendidikan dasar dan menengah dan mengacu pada silabus(Sastrawijaya, 1988).

Diantara berbagai pengajaran individual pengajaran modul berbasis saintifik termasuk metode yang paling baru untuk menggabungkan keuntungan-keuntungan dari berbagai pengajaran individual. Lainnya seperti tujuan instruksional khusus, belajar menurut kecepatan masing-masing(S. Nasution, 2003: 204-205).

Modul digunakan oleh guru sebagai salah satu sumber belajar yang dijadikan media pembelajaran. Media belajar merupakan informasi, alat, dan teks, yang diperlakukan guru untuk perencanaan dan penelaahan implementasi pembelajaran(Hosnan, 2014 : 34). Modul sebagai sumber belajar utama dalam proses pembelajaran. Modul ini telah mencakup seluruh Standar Kompetensi dan Kompetensi Dasar untuk mencapai kompetensi lulusan minimal tingkat Sekolah Menengah Atas (SMA)(Hosnan, 2014:37).

Berdasarkan hasil observasi di yang dilakukan peneliti di SMAN 13 Medan menunjukkan bahwa penggunaan bahan pembelajaran berupa modul belum maksimal dipergunakan di setiap kelas. Dikarenakan pada saat pembelajaran guru lebih banyak menggunakan buku paket dan dibantukan alat peraga dibandingkan modul. Hal inilah yang melatar belakangi peneliti melakukan penelitian pengembangan bahan pembelajaran berupa modul yang diharapkan dapat membantu siswa-siswi dalam proses belajar. Dengan adanya pengembangan modul diharapkan siswa dapat melaksanakan kegiatan pembelajaran dengan menuangkan ide-ide kreatif baik secara perorangan maupun kelompok mampu berpikir kritis dan menjalin kerja sama yang baik dengan anggota kelompok. Selain itu tujuan dari penelitian pengembangan modul berorientasi pendekatan saintifik pada pelajaran Kimiadiharapkan memperoleh kriteria valid, dan efektif.

\section{METODE PENELITIAN}

\subsection{Jenis Penelitian}

Jenis penelitian ini adalah penelitian pengembangan atau Research and Development (R\&D).

\subsection{Waktu Penelitian}

Waktu penelitian dilakukan selama 6 bulan terhitung dari februari 2020 s/d juli 2020. Penelitian ini dimulai dari wawancara analisis kebutuhan hingga penyelesaian laporan skripsi secara keseluruhan.

\subsection{Subjek Penelitian}

Subjek dalam penelitian ini adalah guru kimia SMA Negeri 13 Medan dan dosen kimia UISU.

\subsection{Prosedur Penelitian}

Metode yang digunakan dalam penelitian ini adalah Research and Development (R\&D) dengan model ADDIE yang terdiri dari lima tahap yaitu Analysis (Analisis), Design (Perancangan), Development (Pengembangan), Implementation (Implementasi) dan Evaluation (Evaluasi) dikembangkan oleh Dick and Carry (1996). Pengembangan model ADDIE ini sering digunakan dalam penelitian dan pengembangan 
bahan ajar seperti modul, LKS, RPP dan buku ajar. Berdasarkan tahap pengembangan model ADDIE yang dijelaskan oleh Endang Mulyaningsih (2012: 183).

\subsection{Teknik Pengumpulan Data}

Untuk mengetahui kualitas dari perangkat pembelajaran yang dikembangkan maka digunakan angket sebagai penilaian. Angket atau kuisioner merupakan metode pengumpulan data yang dilakukan dengan cara memberi seperangkat pertanyaan atau pertanyaan tertulis kepada responden sesuai dengan permintaan pengguna (Widyoko, $2012: 33$ ).

\subsection{Teknik Analisis Data}

Menganalisis data adalah salah satu langkah yang kritis dalam penelitian dan metode yang digunakan dalam penelitian ini adalah metode statistik deskriptif, yaitu data yang dianalisis hanya menurut isinya, sedangkan data kuantitatif adalah data dalam bentuk bilangan (Suryabrata, 2003:40). Adapun langkahlangkah sebagai berikut :

\section{a. Data Kuantitatif}

Analisis kualitas instrumen menggunakan angket penelitian perangkat pembelajaran (RPP dan MODUL) untuk ahli materi dan guru kimia. Analisis data angket peniliaian menggunakan analisis deskriptif dengan langkah-langkah sebagai berikut :

1. Menghitung rata-rata jumlah skor yang diperoleh dengan rumus :

$$
x=\frac{\sum x}{\mathrm{n}}
$$

Dengan :

$x \quad$ : Skor rata-rata

$\sum x:$ Jumlah skor yang diperoleh

$\mathrm{n} \quad$ : Banyaknya validator

2. Mengkonversi nilai rata-rata yang diperoleh menjadi data kualitatif

Tabel 1. Kategori Penilaian Skala Lima (Widyoko,2012)

\begin{tabular}{lll}
\hline No & Rerata Skor & Klasifikasi Sikap \\
\hline 1 & $4,2<x \leqslant 5$ & Sangan Baik \\
\hline 2 & $3,4<x \leqslant 4,2$ & Baik \\
\hline 3 & $2,6<x \leqslant 3,4$ & Kurang Baik \\
\hline 4 & $1,8<x \leqslant 2,6$ & Tidak Baik \\
\hline 5 & $1.0<x \leqslant 1,8$ & Sangat Tidak Baik \\
\hline
\end{tabular}

TabeL 2. Kriteria Kevalidan Perangkat Pembelajaran (RPP dan MODUL) (Widyoko,2012)

\begin{tabular}{lll}
\hline No & Rerata Skor & Klasifikasi Sikap \\
\hline 1 & $4,2<x \leqslant 5$ & Sangan Valid \\
\hline 2 & $3,4<x \leqslant 4,2$ & Valid \\
\hline 3 & $2,6<x \leqslant 3,4$ & Kurang Valid \\
\hline 4 & $1,8<x \leqslant 2,6$ & Tidak Valid \\
\hline 5 & $1.0<x \leqslant 1,8$ & Sangat Tidak Valid \\
\hline
\end{tabular}




\section{HASIL DAN PEMBAHASAN}

\subsection{Hasil Penelitian}

\section{Perangkat Pembelajaran (RPP)}

a. Data Uji Kelayakan Oleh Guru Kimia

Uji kelayakan oleh guru kimia bertujuan untuk mengetahui kelayakan materi dan kesesuaian RPP dengan silabus. Dalam uji kelayakan ini dilakukan oleh 2 orang guru kimia yaitu ibu Elizar Noviana, S.Pd.,M.Si (guru kimia SMA Negeri 13 Medan) dan ibu Nur Aisyah,S.Pd (guru kimia SMA Pondok Pesantren Modren Darul Hikmah TPI Medan).Guru kimia menilai RPP yang dikembangkan oleh peneliti dengan pengisian angket yang sudah disediakan oleh peneliti kusus untuk guru kimia. Angket tersebut terdiri dari 27 butir pernyataan yang terbagi menjadi 6 aspek penilaian.

Tabel 3. Kelayakan RPP Oleh Guru Kimia

\begin{tabular}{|c|c|c|c|c|c|c|c|}
\hline \multirow[t]{2}{*}{ Aspek } & \multicolumn{2}{|c|}{ Nilai } & \multirow[t]{2}{*}{ Item } & \multirow{2}{*}{$\begin{array}{l}\text { Skor } \\
\text { Total }\end{array}$} & \multirow[t]{2}{*}{ F.H } & \multirow[t]{2}{*}{$\%$} & \multirow[t]{2}{*}{ Keterangan } \\
\hline & G.Km & G.Km 2 & & & & & \\
\hline Identitas RPP & 18 & 17 & 4 & 37 & 40 & 93 & S. layak \\
\hline $\begin{array}{l}\text { Rumusan } \\
\text { Indikator }\end{array}$ & 8 & 8 & 2 & 16 & 20 & 80 & Layak \\
\hline Pemilihan Materi & 16 & 16 & 4 & 32 & 40 & 80 & Layak \\
\hline Kegiatan saintifik & 44 & 43 & 11 & 87 & 110 & 79 & Layak \\
\hline Memilih Media & 12 & 12 & 3 & 24 & 30 & 80 & Layak \\
\hline \multirow[t]{3}{*}{ Hasil Belajar } & 12 & 12 & 3 & 23 & 30 & 77 & Layak \\
\hline & \multicolumn{5}{|c|}{ Jumlah } & 489 & \multirow{2}{*}{ S. layak } \\
\hline & & & Rata-r & & & 82 & \\
\hline
\end{tabular}

Keterangan :

Frekuensi harapan : Nilai frekuensi maksimal skala 5

Item : Jumlah butir pernyataan

Hasil yang diperoleh dari perhitungan pada tabel 5 memperlihatkan bahwa dari guru kimia, RPP berbasis saintifik secara keseluruhan tergolong "sangat layak" dengan hasil rata-rata kelayakan " $82 \%$ ". 


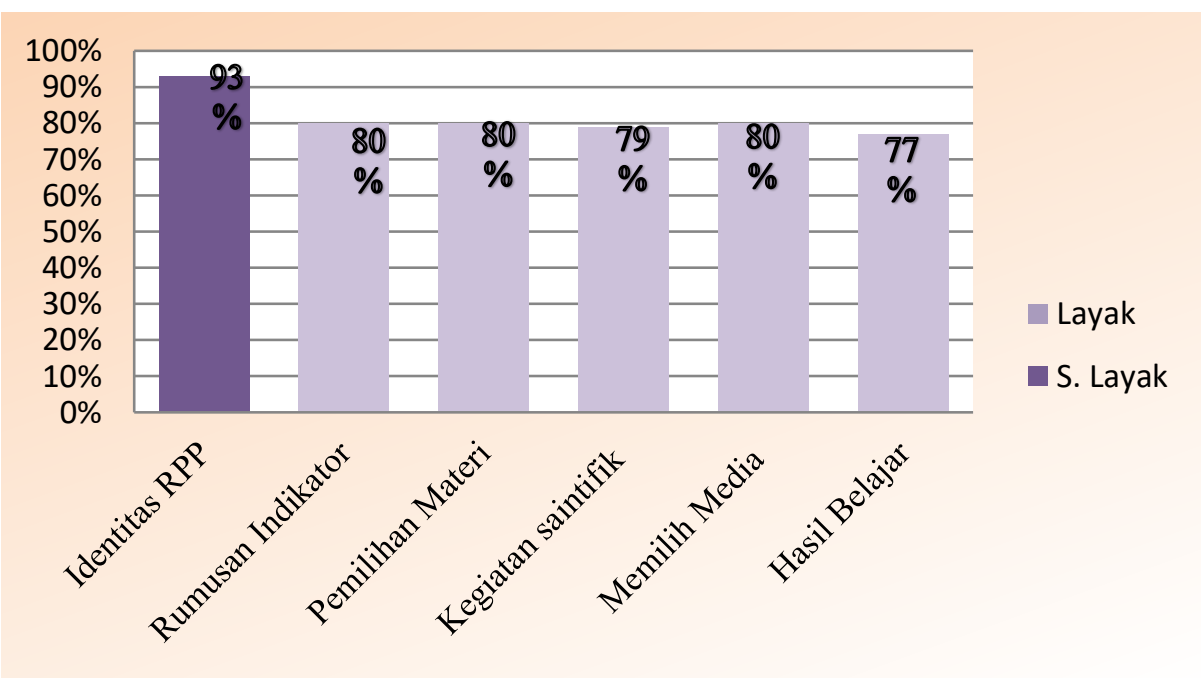

Gambar 1 Grafik persenan kelayakan RPP dari aspek guru kimia

\section{Modul}

\section{a. Data Uji Kelayakan Oleh Ahli Materi}

Uji kelayakan modul pembelajaran oleh ahli materi bertujuan untuk mengetahui kelayakan dan kesesuaian materi dengan silabus. Dalam uji kelayakan ini dilakukan oleh 2 orang ahli materi yaitu ibu Elizar Noviana, S.Pd.,M.Si (guru kimia SMA Negeri 13 Medan) dan ibu Nur Aisyah,S.Pd (guru kimia SMA Pondok Pesantren Modren Darul Hikmah TPI Medan). Ahli materi menilai modul pembelajaran yang dikembangkan oleh peneliti dengan pengisian angket yang sudah disediakan oleh peneliti kusus untuk ahli materi. Angket tersebut terdiri dari 46 butir pernyataan yang terbagi menjadi 3 aspek penilaian.

Tabel 4. modul aspek materi

\begin{tabular}{|c|c|c|c|c|c|c|c|}
\hline \multirow[t]{2}{*}{ Aspek } & \multicolumn{2}{|c|}{ Nilai } & \multirow[t]{2}{*}{ Item } & \multirow{2}{*}{$\begin{array}{l}\text { Skor } \\
\text { Total }\end{array}$} & \multirow[t]{2}{*}{ F.H } & \multirow[t]{2}{*}{$\%$} & \multirow{2}{*}{$\begin{array}{l}\text { Keteranga } \\
\text { n }\end{array}$} \\
\hline & A.Ma & A.Man & & & & & \\
\hline Kelayakan isi & 75 & 70 & 20 & 145 & 200 & 73 & Layak \\
\hline Aspek penyajian & 53 & 46 & 13 & 99 & 130 & 77 & Layak \\
\hline \multirow[t]{3}{*}{ Penilaian bahasa } & 57 & 55 & 13 & 102 & 130 & 79 & Layak \\
\hline & & & \multicolumn{2}{|c|}{ Jumlah } & & 229 & Layak \\
\hline & & & \multicolumn{2}{|c|}{ Rata-rata } & & 77 & \\
\hline
\end{tabular}

Keterangan :

$>$ Frekuensi harapan : Nilai frekuensi maksimal skala 5

$>$ Item : Jumlah butir pernyataan

Hasil yang diperoleh dari perhitungan pada tabel 6 memperlihatkan bahwa dari aspek materi, modul berbasis saintifik secara keseluruhan tergolong "layak" dengan hasil rata-rata kelayakan "77\%". 


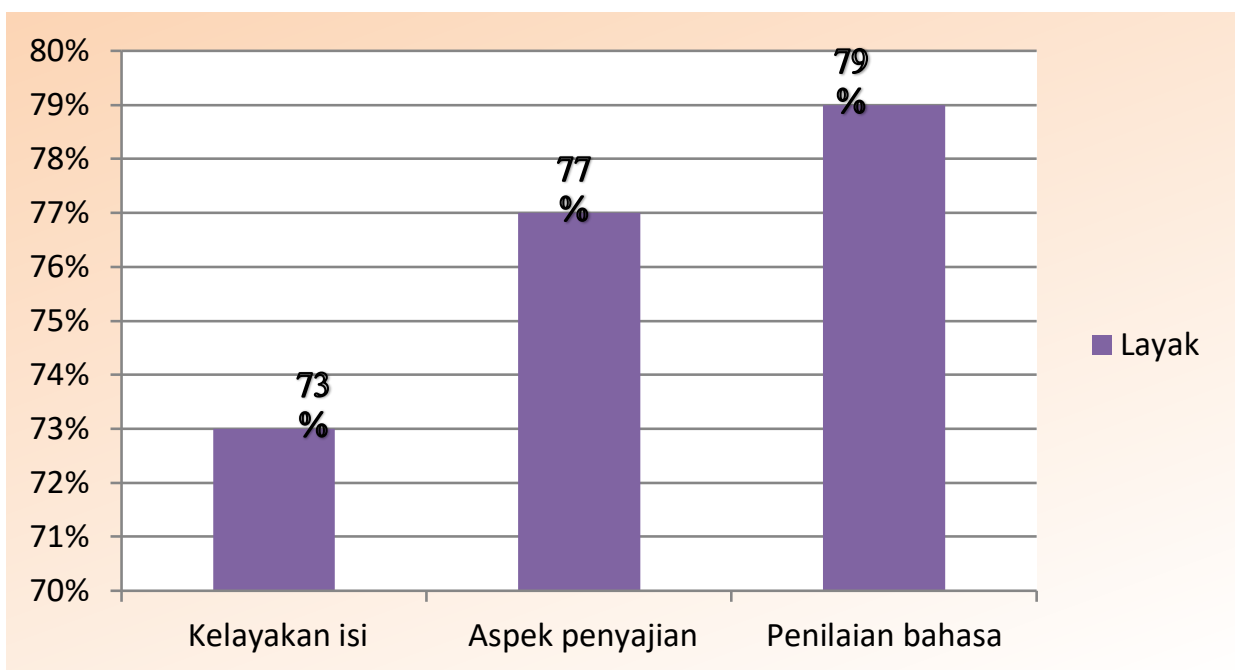

Gambar 2 Grafik persenan kelayakan modul dari aspek materi

\section{b. Data Uji Kelayakan Oleh Ahli Media}

Uji kelayakan modul pembelajaran oleh ahli media bertujuan untuk mengetahui kelayakan dari segi media pembelajaran. Dalam uji kelayakan ini dilakukan oleh 2 orang ahli media yaitu ibu Adilah Wirdhani Lubis, S.Pd.,M.Si (dosen pendidikan kimia UISU ) dan ibu Uswatun Hasanah,S.,M.Pd (dosen pendidikan kimia UISU). Ahli media menilai modul pembelajaran yang dikembangkan oleh peneliti dengan pengisian angket yang sudah disediakan oleh peneliti kusus untuk ahli media. Angket tersebut terdiri dari 14 butir pernyataan yang terbagi menjadi 5 aspek penilaian.

Tabel 5. modul aspek media

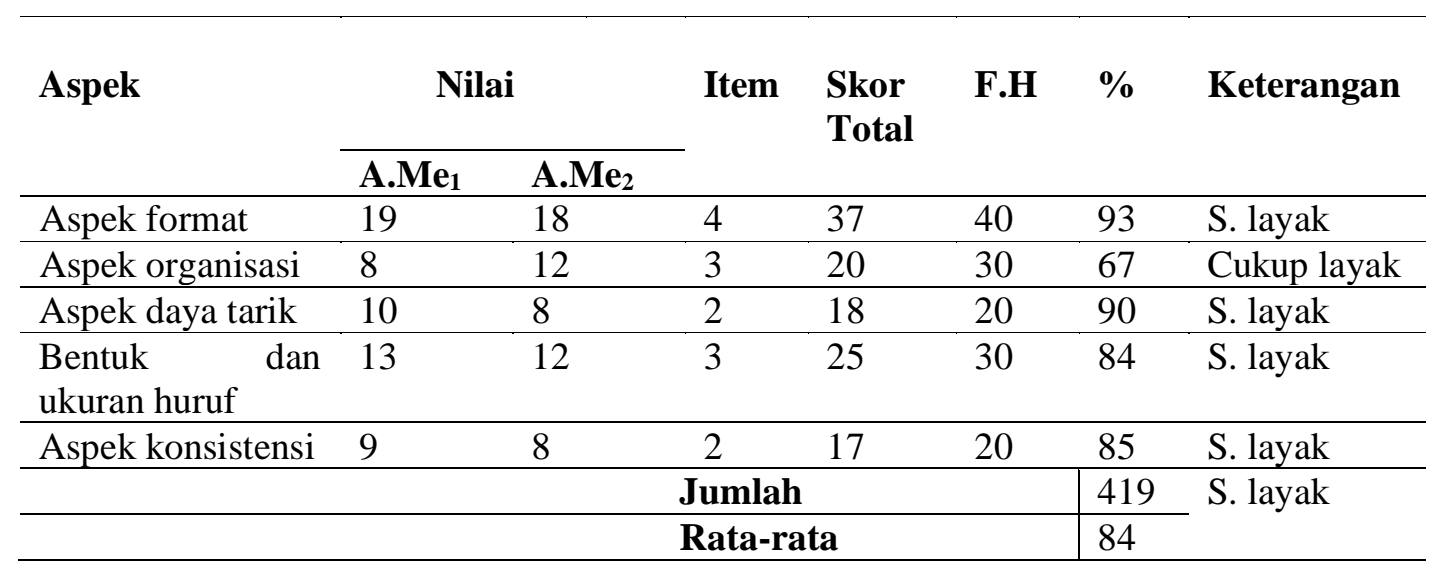

Keterangan :

$>$ Frekuensi harapan : Nilai frekuensi maksimal skala 5

Item : Jumlah butir pernyataan

Hasil yang diperoleh dari perhitungan pada tabel 7 memperlihatkan bahwa dari aspek media, modul berbasis saintifik secara keseluruhan tergolong "sangat layak" dengan hasil rata-rata kelayakan "84\%". 


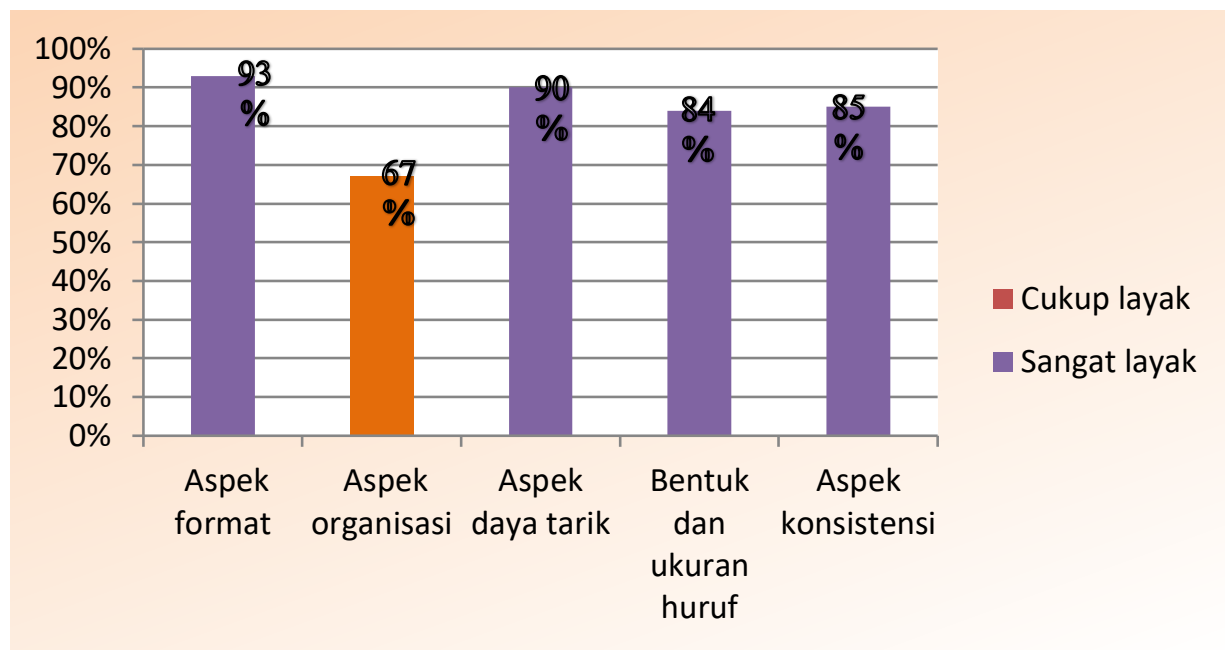

Gambar 3 Grafik persenan kelayakan modul dari aspek media

\subsection{Pembahasan}

Setelah dalam penelitian ini dilakukan perhitungan data yang sudah diperoleh bahwa nilai ratarata kelayakan RPP berbasis saintifik berdasarkan nilai yang diperoleh dari guru kimia sebesar $82 \%$ dengan kategori sangat layak. Begitu pula dengan penilaian kelayakan modul pembelajaran tata nama senyawa berbasis saintifik yang sudah diperoleh dari ahli materi sebesar $77 \%$ dengan kategori layak dan penilaian dari ahli media sebesar $84 \%$ dengan kategori sangat layak sehingga dapat diketahui rata-rata kelayakan modul secara keseluruhan memiliki persentasi $81 \%$ dengan kategori sangat layak. Sehingga RPP dan modul pembelajaran tata nama senyawa berbasis saintifik dapat dipergunakan bagi sekolah khususnya sekolah yang menjadi sasaran peneliti. Hasil uji kelayakan yang dilakukan oleh guru kimia, ahli materi dan ahli media kemudian dilakukannya revisi oleh peneliti guna untuk memperbaiki RPP dan modul pembelajaran tata nama senyawa berbasis saintifik sehingga layak digunakan pada proses belajar mengajar kimia khususnya pada materi tata nama senyawa kelas X.

\section{SIMPULAN DAN SARAN}

\subsection{Simpulan}

Berdasarkan hasil dan pembahasan dalam penelitian pengembangan ini, maka dapat ditarik kesimpulan sebagai berikut :

1. Penelitian ini menghasilkan produk berupa RPP dan modul pembelajaran tata nama senyawa berbasis saintifik. RPP dan modul pembelajaran mengacu kepada silabus yang berlaku disekolah sasaran peneliti tersebut dan penyusunan RPP dan modul pembelajaran mengikuti standar penyusunan RPP dan modul pembelajaran yang berlaku sesuai dengan standar Depdiknas.

2. Kelayakan RPP berbasis saintifik berdasarkan penilaian yang diperoleh secara keseluruhan tergolong sangat layak dengan rata-rata nilai kelayakan $82 \%$ dengan kategori sangat layak.

3. Demikian pula dengan penilaian kelayakan modul pembelajaran berbasis saintifik yang diperoleh secara keseluruhan tergolong sangat layak dengan rata-rata nilai kelayakan $81 \%$ dengan kategori sangat layak. Nilai pada masing-masing ahli materi $77 \%$ dengan kategori layak dan ahli media $84 \%$ dengan kategori sangat layak. 


\subsection{Saran}

Berdasarakan penelitian pengembanganini, maka saran yang dapat peneliti berikan sebagai berikut

1. Perangkat pembelajaran yang dikembangkan sebaiknya tidak hanya satu RPP saja sehingga dapat mengembangkan silabus.

2. RPP berbasis saintifik sebaiknya digunakan oleh guru pengampu mata pelejaran kimia sebagai masukan perangkat pembelajaran materi tata nama senyawa dalam penyususnan strategi pembelajaran.

3. Modul pembelajaran berbasis saintifik sebaiknya digunakan oleh guru kimia kelas X SMA/MA sebagai masukan bahan ajar pada materi tata nama senyawa dalam meningkatkan kinerja guru dan peserta didik.

4. Bagi peneliti selanjutnya, dapat melakukan validasi pengembangan RPP dan modul pembelajaran berbais saintifik sampai pada tahap validasi evaluasi penilaian respon siswa.

\section{DAFTAR PUSTAKA}

Ahmad, S. 2013 'Problematika Kurikulum 2013 dan Kepemimpinan Instruksional Kepala Sekolah', Jurnal pencerahan, 8(2), pp. 98-108.

Ferdinandus. 2014. Ini Delapan Masalah dalam Implementasi Kurikulum 2013. https://m.metrotvnews.com/read/2014/10/19/307023/ini-delapan-masalah-dalam-implementasikurikulum-2013 (diakses tanggal 21 Juni 2015 pukul 20.15)

Gurney, Philip. 2007. "Five Factors for Effective Teaching". New Zealand Journal ofTeacher's Work Vol.

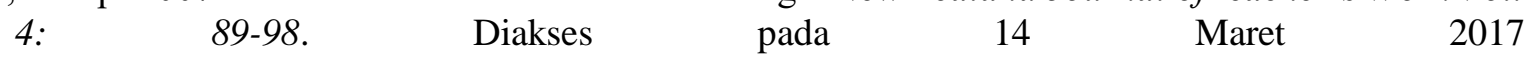
(www.teacherswork.ac.nz/journal/volume4_issue2/gurney.pdf)

Harahap, Rachmad Faisal. 2015. Dua Tahun Lagi Semua Sekolah Pakai Kurikulum 2013.http://m.okezone.com/read/2015/03/16/dua-tahun-lagi-semua-sekolah-pakai-kurikulum2013? =utm_source=br. (diakses tanggal 21 Juni 2015 pukul 20.00)

Hidayati. 2006. Instrumen dan Alat Bantu. Graha Ilmu. Yogyakarta

Hosnan, 2014.Pendekatan Saintifik Dan Kontekstual Dalam Pembelajaran Abad 21 Kunci Sukses Implementasi Ku-rikulum 2013. Bogor: Ghalia Indonesia.

Maisyaroh, W. et al. 2014 'Masalah guru dalam implementasi kurikulum 2013 dan kerangka model supervisi pengajaran', Manajemen Pendidikan, 24(3), pp. 213-220 